\title{
Fitness Test in Measuring Aerobic Fitness in National Physical Fitness Award (NAPFA) of Secondary Two Students 2.4 公里酎力跑與20米往返跑在新加坡全國體能测驗中 测試中二學生心肺功能的關係
}

\author{
CHEN Hui Jia WONG Shiying \\ OR Vin Fern Ivy QUEK Chin Hwee Steven \\ River Valley High School, SINGAPORE
}

陳慧佳 黃詩預 胡敏芬 郭進輝

新加坡立化中學

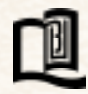

\begin{abstract}
This study aims to investigate the correlation between the $2.4 \mathrm{~km}$ Run-Walk Test and the Multi-stage Fitness Test (MST) in measuring aerobic fitness in the National Physical Fitness Award (NAPFA) of Secondary 2 students in Singapore. 187 Secondary 2 students (age 14 years) of a mixed gender secondary school were recruited for the study. Subjects performed the $2.4 \mathrm{~km}$ Run-Walk Test and the MST. The VO2 max level obtained from both tests were compared using the Pearson correlation coefficient analysis and Paired-sample t-test. Pearson correlation coefficient analysis shows that the predicted VO2 $\max$ from the two tests share a strong positive correlation with $\mathrm{r}=0.78$. However, Paired-sample $t$-test shows that VO2 $\max$ predicted by the $2.4 \mathrm{~km}$ Run-Walk test is significantly $(\mathrm{t}=13.82, \mathrm{p}<0.05)$ greater (mean $=36.70 \mathrm{~L} / \mathrm{min}, \mathrm{SD}=4.32$ ) than that predicted by MST (mean $=33.60 \mathrm{~L} / \mathrm{min}, \mathrm{SD}=4.91$ ). Results of the present study suggest that both the MST and $2.4 \mathrm{~km}$ Run-Walk test can measure aerobic fitness of 14-year old participants for NAPFA. In unfavourable weather, the MST can replace the $2.4 \mathrm{~km}$ Run-Walk Test. Further research can be done to enhance the test setting and environmental factors, as well as to include subjects of other age groups and ethnicities, to obtain a more holistic perspective on the interchangeability of the two tests for NAPFA assessment.
\end{abstract}

\section{摘 要}

本文旨在探討 2.4 公里耐力跑與 20 米每分鐘遞增速度往返跑測驗（簡稱 20 米往返跑）在新加坡全國體能測驗中測試中二學生 心肺功能的關係。本研究對187名男女同校的中二學生 (14歲) 進行2.4公里耐力跑與20米往返跑。接著, 從這兩項測驗中預測 學生最大吸氧量, 採用積差相關係數與相依樣本 T監定進行檢驗。積差相關係數顯示 2.4 公里耐力跑與 20 米往返跑預測的最大 吸氧量正相關 $(\mathrm{r}=0.78)$ 。相依樣本 $\mathrm{T}$ 鑒定顯示 2.4 公里耐力跑預測的最大吸氧量顯然 $(\mathrm{t}=13.82, \mathrm{p}<0.05)$ 高於 $(\mathrm{mean}=36.70 \mathrm{~L} / \mathrm{min}$, $\mathrm{SD}=4.32$ ) 20 米往返跑預測的最大吸氧量 (mean=33.60 L/min, SD=4.91)。研究結果顯示, 2.4 公里耐力跑與 20 米往返跑可用於新 加坡全國體能測驗, 是測試新加坡中二學生心肺功能的可靠方法。若天氣不佳, 20 米往返跑可取代 2.4 公里耐力跑。為了在現有 的基礎上加強實驗的整體設定, 以及減少環境因素造成的影響, 可以進行更深入調查。其外, 也可以從不同年齡和種族背景方面 擴大研究物件, 從一個更全面的角度研究並分析這兩種測驗在新加坡全國體能測驗的可替換性。 


\section{Introduction}

The National Physical Fitness Award (NAPFA) is a test of physical fitness for Singaporeans. Introduced by the Singapore Sports Council in 1981, it is part of the country's "Sports For Life" programme to promote sports to the general population. The NAPFA consists of six test items. They are (1) Sit-up, (2) Standing Broad Jump, (3) Sit and Reach, (4a) Pull-ups (for males 15 years and above only), (4b) Inclined Pullups (for all females, and males up to the age of 14), (5) Shuttle Run and (6) $2.4 \mathrm{~km}$ or $1.6 \mathrm{~km}$ Run-Walk (for primary school children). All six test stations have to be completed on the same day except the RunWalk item, which may be attempted on a different day, but only under certain conditions. Performances of each test item are compared to a chart and graded from A to F. An A grade constitutes excellent performance, an $\mathrm{E}$ grade constitutes barely passing and an $\mathrm{F}$ grade indicates that the participant has failed that test item. Points are also awarded for each test item and the total score determines if the participant has achieved a Gold, Silver or Bronze award (Singapore Sports Council, 2002).

Since 1982, the Ministry of Education (MOE) has adopted the NAPFA test for their annual fitness assessment in schools and made it compulsory for all students, starting from Primary 4 (10 years old) onwards. Students are required to complete the 5 test stations and a $1.6 \mathrm{~km}$ Run-Walk (primary school) or a $2.4 \mathrm{~km}$ Run-Walk (secondary school). Students, with the exception of the NS pre-enlistee, are allowed to complete the $2.4 \mathrm{~km}$ or $1.6 \mathrm{~km}$ Run-Walk test on another day. However, both sessions have to be completed within two weeks of each other (Singapore Sports Council, 2002).

The Ministry of Defence (MINDEF) also uses NAPFA as the Individual Physical Proficiency Test (IPPT), to assess the physical fitness of pre-enlistees, active servicemen and reservists in the Singapore Armed Forces (SAF). The IPPT is similar to the NAPFA except that the Sit-and-Reach item is excluded. Prior to mandatory enlistment, males at the age of 18 have to take the NAPFA. Based on their scores, pre-enlistees who fail to achieve a Gold or Silver Award need to attend 2 additional months of Physical Training Phase (PTP) to improve fitness, before they begin Basic Military Training (BMT). Active servicemen and reservists are also required to meet the annual IPPT requirement, which varies according to age and medical status. Those who fail to meet these requirements have to undergo remedial training to improve fitness (Ministry of Defence, 2008).

From the long-term climate data gathered at Meteorological Service Singapore, there are approximately 178 days of rainfall and 187 days with lightning in Singapore annually (National Environmental Agency, 2013). With the country experiencing rain or lightning almost every other day of the year, there is a strong possibility that wet weather conditions may disrupt the NAPFA test. There is no restriction on the conduct of NAPFA indoor or outdoor so five of the test items could be conducted indoor. However, in most cases, it is impossible for schools or military camps to have sufficient open indoor space to conduct the $2.4 \mathrm{~km}$ Run-Walk test without compromising safety or the integrity of the test. As the national service pre-enlistees and national servicemen are required to complete all test stations in a single session, in the case of a downpour or when lightning is detected within the vicinity, participants who are unable to complete the outdoor $2.4 \mathrm{~km}$ Run-Walk test would have to retake all stations on another date. Considering the packed curriculum in schools, as well as the demanding military training of the servicemen, each re-scheduling of the test would put much strain on the valuable time and resources on the school or military institutions.

Besides the problem of wet weather conditions, Singapore's climate is characterized by high humidity and temperature. Average relative humidity of the country is above $80 \%$ and after a heavy downpour, relative humidity could reach $100 \%$. The average monthly high temperature is $31^{\circ} \mathrm{C}$, and the highest recorded temperature went as high as $36^{\circ} \mathrm{C}$. With such harsh weather conditions, it is tough for the students and servicemen to be running outdoors in the late morning or early afternoon. They may even risk sustaining serious heat injuries. To reduce the strain and the risk of fatalities, administrators in schools and military institutions schedule NAPFA test in the early morning or the evening. This poses a challenge as administrators compete for the limited time slots in the early morning or evening of the working day.

Apart from the $2.4 \mathrm{~km}$ Run-Walk test, the Multistage Fitness Test (MST) is another common test used to evaluate cardiovascular fitness (Leger et al., 1988). The test involves running continuously between two points that are 20 meters apart. These runs are synchronized 
with a pre-recorded beep tone. As the test proceeds, the time interval between each successive beep decreases, forcing the participant to increase the speed until it is impossible to keep up with the pace of the recording. The highest level attained in this test gives a measure of the cardiorespiratory fitness of the participant.

Maximal oxygen uptake (VO2 max) is the highest rate of oxygen consumption attainable during maximal or exhaustive exercise. It is an indicator of the cardiorespiratory capacity for oxygen transport to active tissues as well as the ability of these tissues to utilise oxygen (Southard \& Pugh, 2004). Direct measurement of maximal oxygen uptake using gas analysis is universally accepted as a standard of reference for assessment of aerobic power (Howley et al., 1995). Such direct measure of $\mathrm{VO} 2 \max$ is, however, not practical on a large scale as expensive equipment and individual supervision are required. Indirect measure is often used to measure $\mathrm{VO} 2$ max instead.

Many studies have proven the validity of indirect VO2 max tests such as $2.4 \mathrm{~km}$ Run-Walk test and MST in measuring aerobic fitness, by comparing them against direct VO2 max tests. Gardner (2004) conducted two experiments, the MST and a laboratory testing of direct gas analysis using Monark cycle ergometer. The tests concluded that the mean maxHR scores between the two experiments were virtually identical; signifying that the MST can be used as a reliable source for testing VO2 max. In a separate experiment, Clauzon (2002) tested the MST against the direct gas analysis using a treadmill. However, the mean scores were 23\% lower for the MST. He hypothesized that participants executing the MST may not have reached their maximal oxygen uptake before the test was terminated. Burger et al. (1990) conducted a study to assess the validity of the $2.4 \mathrm{~km}$ Run-Walk test as an indicator of aerobic capacity, by comparing the VO2 max obtained from the $2.4 \mathrm{~km}$ RunWalk test and the VO2 max measured using a treadmill test. It was concluded that the $2.4 \mathrm{~km}$ Run-Walk test is significantly correlated to the directly measured VO2 $\max$ and therefore, is a reliable alternative measure of aerobic capacity. However, few studies on the correlation between indirect VO2 max tests are available on scientific literature. One such study done by Aziz et al. (2005) found out a significant correlation $(r=0.65, p<0.01)$ between the MST and the Yo-Yo intermittent endurance test in the performance of soccer players, using the Pearson correlation coefficient analysis.
Unlike the $2.4 \mathrm{~km}$ Run-Walk test, MST can readily be carried out indoors due to the space required. By substituting the $2.4 \mathrm{~km}$ Run-Walk test with the MST in NAPFA assessment, problems caused by wet weather can be eliminated. However, the MST has its limitations. A smaller group of people can take the test at one point in time, unlike the $2.4 \mathrm{~km}$ Run-Walk test. It may be more challenging to carry out the MST for a large group of people.

This research aims to investigate the correlation between the MST and $2.4 \mathrm{~km}$ Run-Walk test. The hypothesis of the current study states that a positive correlation exists between the two test items.

\section{Methodology}

\section{Subjects}

A total of 187 Secondary 2 students (14-year-old) of a mixed gender secondary school participated in this research.

\section{Multi-stage Fitness Test (MST)}

The objective of the Multi-stage Fitness Test (MST) is to measure the participant's VO2 max. The test is made up of 23 levels where each level lasts approximately 1 minute. Each level comprises of a series of 20 meter shuttles where the starting speed is $8.5 \mathrm{~km} / \mathrm{hr}$ and increases by $0.5 \mathrm{~km} / \mathrm{hr}$ at each level (Leger et al., 1982).

Participants ran back and forth between the 20 meter shuttles, in time with the "beep" sounds from a compact disc (20-m shuttle run test CD). Each successful run of the 20-m distance was a completion of a shuttle. The participant was informed if he did not reach the end line in time once. The test was terminated when he could not follow the set pace of the "beeps" for two successive shuttles, and/or stopped voluntarily. The number of stages and levels completed by the participant was recorded (Aziz et al., 2005). The VO2 max level was then obtained using a conversion table (Ramsbottom et al., 1988).

\section{4 km Run-Walk Test}

Participants completed 6 laps of a standard 400 metre track. The total time taken to complete the course was recorded. The VO2 max level was calculated using the formula: 
$\mathrm{VO} 2 \max =483 / \mathrm{t}+3.5$ (given that $\mathrm{t}$ is the timing of the $2.4 \mathrm{~km}$ Run-Walk test in minutes) (Cooper, 1997)

\section{Statistical Analysis}

From the VO2 max level obtained from the 2 tests, the mean, mean difference, standard deviation and p-value of each physical test was found and compared using the Pearson correlation coeffiecient analysis and Paired-sample t-test.

\section{Results}

In Figure 1, VO2 max score predicted from the 2.4 $\mathrm{km}$ Run-Walk test is plotted against the VO2 $\max$ score predicted from the MST of each student.

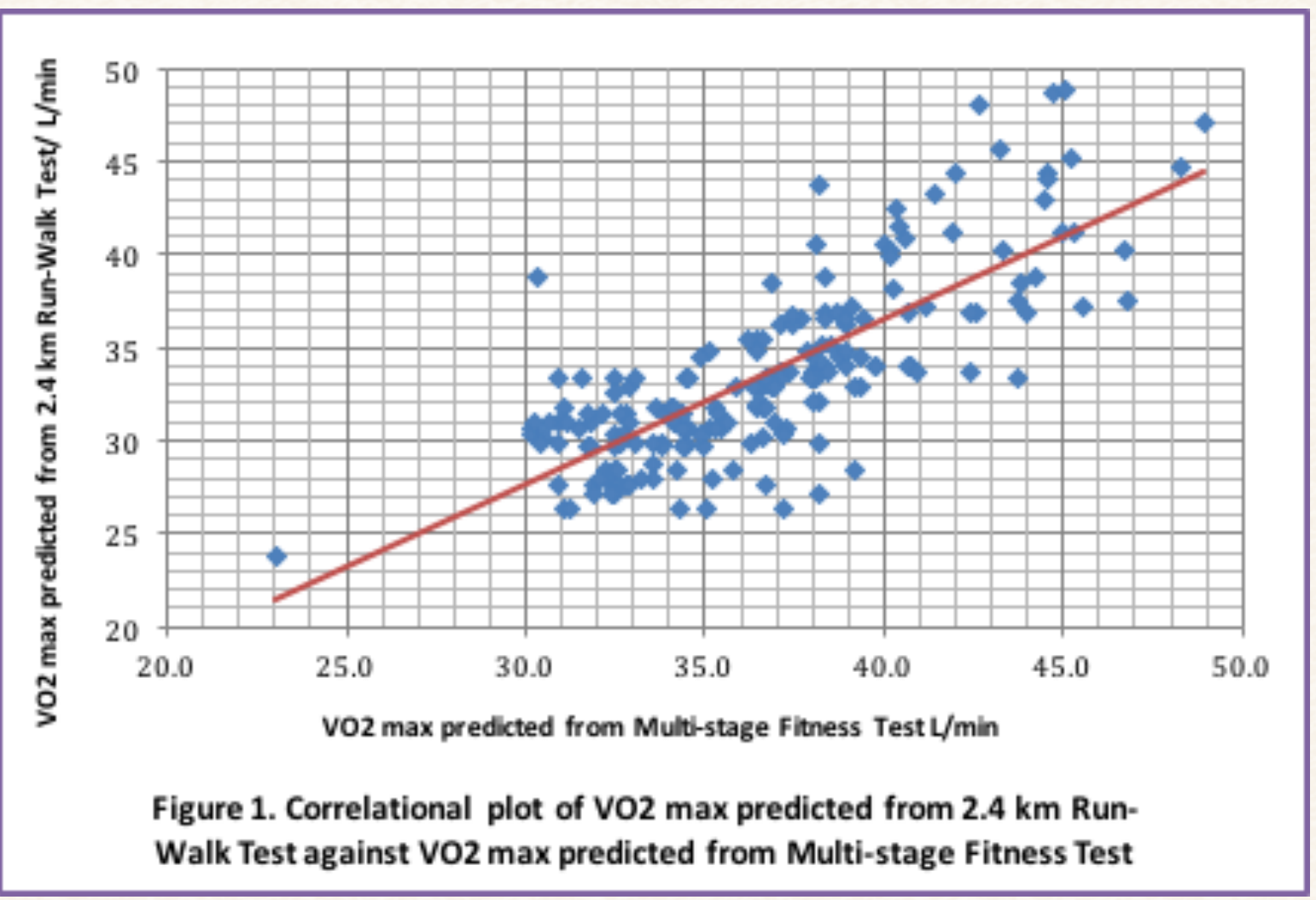

Pearson product-moment correlation coefficient: $r=0.78$

The general trend shows increasing VO2 max predicted from the $2.4 \mathrm{~km}$ Run-Walk test, with increasing VO2 max predicted from the MST. Statistical analysis of the raw data has also indicated that the two sets of data share strong positive correlation with $\mathrm{r}=0.78$, where the more the Pearson product-moment correlation coefficient, $\mathrm{r}$, is towards 1 , the more positive and linear the relation between the two variables would be.
Hence, the results of this test show that the VO2 max predicted from the $2.4 \mathrm{~km}$ Run-Walk test and the VO2 max predicted from the MST have a linear relationship, meaning that a person with a higher MST score is likely to complete the $2.4 \mathrm{~km}$ Run-Walk test faster. 
Figure 2 shows the mean VO2 max predicted from the $2.4 \mathrm{~km}$ Run-Walk test and mean VO2 predicted from MST.

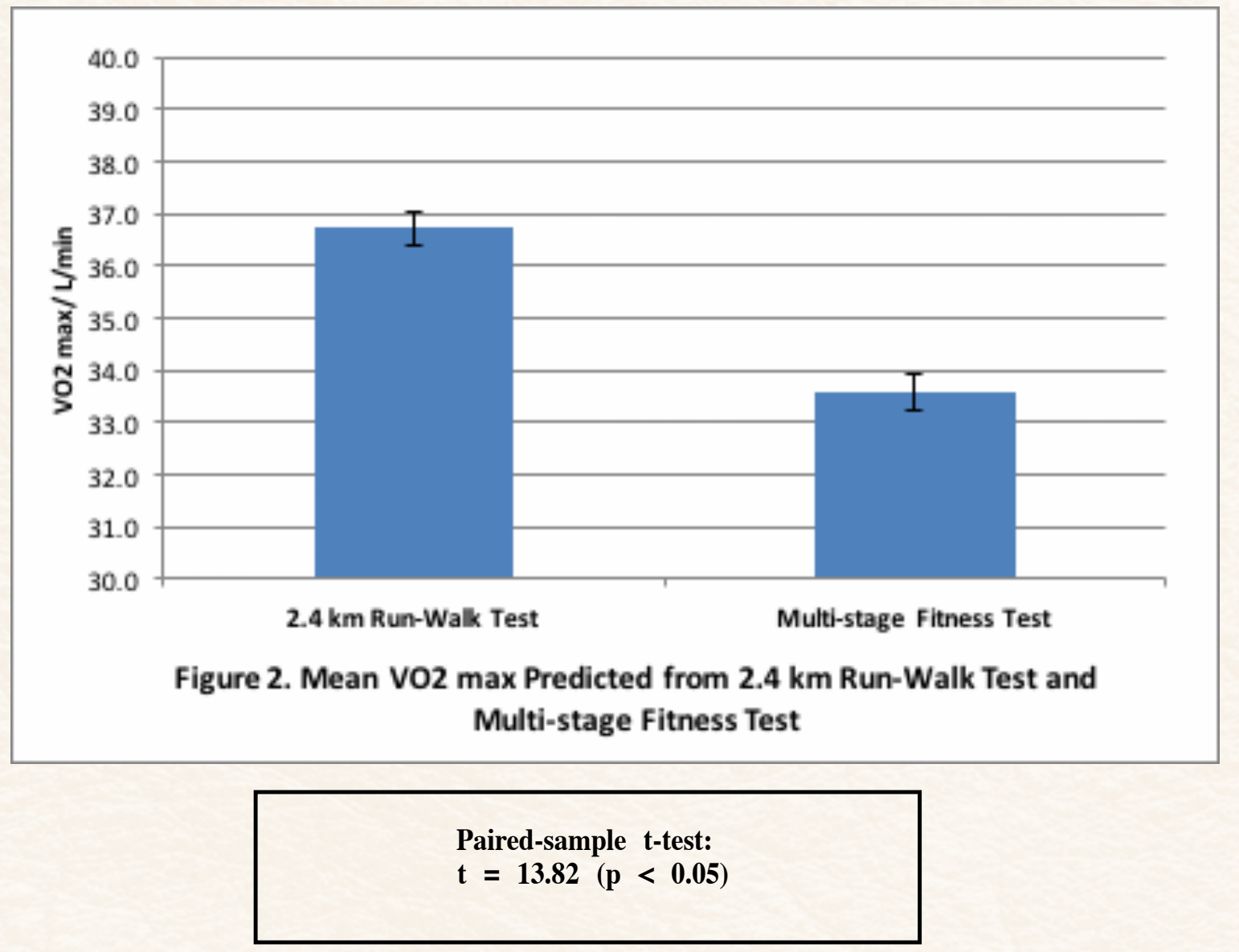

Paired-sample t-test shows that $\mathrm{VO} 2$ max predicted by the $2.4 \mathrm{~km}$ Run-Walk test is significantly $(\mathrm{t}=13.82$, $\mathrm{p}<0.05)$ greater $($ mean $=36.70 \mathrm{~L} / \mathrm{min}, \mathrm{SD}=4.32)$ than that predicted by the MST $($ mean $=33.60 \mathrm{~L} / \mathrm{min}, \mathrm{SD}=4.91$ ).

\section{Discussion}

The results of the Pearson product-moment correlation coefficient suggest that the two tests have a linear relationship. However, the paired-sample t-test suggests that there is a significant difference between the two tests. In general, students have scored lower in the MST as compared to that obtained from the $2.4 \mathrm{~km}$ Run-Walk test. The difference that affected majority of the students may be attributed to the following reasons:

- Participants were less driven for the MST. As both tests are maximal tests which require participants to run to exhaustion to obtain an accurate gauge of the VO2 max, participants have to be motivated to elicit a truly maximal effort. However, in this case, the 2.4 $\mathrm{km}$ Run-Walk test was conducted during the annual NAPFA test while the MST was conducted during a routine Physical Education (PE) lesson. Thus, participants may have been less motivated to put in their best effort for the MST.

- The difference in the nature of the two tests may have affected the results of this research. For the MST, participants have to adhere strictly to the given pace, controlled by successive beep tones between each run. For the $2.4 \mathrm{~km}$ Run-Walk test, participants have to set their own pace for the run. Some participants who are inexperienced in pacing may run flat out from the start of the test or start too slowly, both leading to less than ideal performance. Hence, the gradual progression in the MST should help participants perform better. However, the results from this study show that participants actually performed better in the $2.4 \mathrm{~km}$ Run-Walk test. This 
could be because the Secondary 2 students who participated in this study had practiced running the 2.4 $\mathrm{km}$ course during PE lessons, in preparation for their NAPFA. Hence, they were familiar with pacing and it was not a significant problem. On the other hand, they were performing the MST for the first time and were not familiar with the activity.

- Fitness of participants may have changed due to a considerable lapse of time between the two tests. During this time period, fitness level of participants may have changed due to undergoing a new training programme or due to reversibility of fitness.

To enhance future research, the above limitations can be reduced by:

- The $2.4 \mathrm{~km}$ Run-Walk test and MST can be conducted in the same period of time (within 2 months from each other), with participants randomly assigned with half doing the MST and $2.4 \mathrm{~km}$ RunWalk Test in the first session, to minimize training effects.

- The stakes for the MST can be increased. For example, the MST could be used as part of the overall Physical Education assessment grade. This might serve as an incentive for students to put in their best effort during the test. When the participants are driven to the same extent in the two tests, more accurate VO2 max results will be obtained.

In addition, the current calculation tables and formulas were extracted from Western sources and this may yield different results had Asian norms been available as all the participants are 14-year-old Chinese. A collection of Asian norms and a study on the tables and formulas specific to Asian may give more insights into the issue. For future studies, this research can also be conducted for different age groups to reaffirm if the MST and $2.4 \mathrm{~km}$ Run-Walk test can both be used for NAPFA for other ages.

\section{References}

Based on the results of this study, both the Multistage Fitness Test (MST) and the $2.4 \mathrm{~km}$ Run-Walk test can be used for NAPFA for 14-year-old. The MST can thus replace the $2.4 \mathrm{~km}$ Run-Walk test in case of unfavourable weather, although the $2.4 \mathrm{~km}$ Run-Walk test may still be preferred as it can be conducted with a large group of people at one time. Both tests can thus be used to measure aerobic fitness of participants for NAPFA.

\section{References}

Aziz, A. R., Tan, H. Y., \& Teh, K. C. (2005). A pilot study comparing two field tests with the treadmill run test in soccer players. Journal of Sports Science and Medicine. Retrieved November 24, 2013 from http://www.jssm.org/vol4/n2/3/v4n2-3text.php\#1.

Burger, S. C., Bertram, S. R., \& Stewart, R. I. (1992). Assessment of the $2.4 \mathrm{~km}$ run as a predictor of aerobic capacity. South African Medical Journal 81(11), 580.

Clauzon, R. (2002). A regression equation to predict true VO2max using a field test (20 meter shuttle run). Retrieved July 14, 2013 from http://www.uvm. edu/ clauzon/bleep_vo2max.html.

Cooper, K. H. (1977). The Aerobics Way. New York: Bantam Books.

Gardner, R. (2004). Anatomy \& Physiology, Vo2 MAX, Unpublished manuscript. Retrieved July 14, 2013 from http://www.angelfire.com/alt/richardgardner/ RichardGardnerV2/Vo2MAX.html.

Howley, E. T., Basset, D. R., \& Welch, H. G. (1995). Criteria for maximal oxygen uptake: review and commentary. Official Journal of the American College of Sports Medicine. Retrieved November 24, 2013 from http://www.uni.edu/dolgener/Instrumentation/ Articles/Criteria\%20for\%20VO2max.pdf.

Leger, L.A. \& Lambert, J. (1982). "A maximal multistage $20 \mathrm{~m}$ shuttle run test to predict VO2 max". European Journal of Applied Physiology, 49, 1-5. 
Léger, L.A., Mercier, D., Gadoury, C. \& Lambert, J. (1988). "The multistage 20 metre shuttle run test for aerobic fitness". J Sports Sci 6 (2), 93-101.

Ministry of Defence, (MINDEF). (2008). iPrepNS: NAPFA Test. Retrieved November 24, 2013 from http://iprep. ns.sg/napfa-test.html.

National Environment Agency (NEA). (2013). Weather Statistics. Retrieved December 1, 2013 from http:// app2.nea.gov.sg/weather-climate/climate-information/ weather-statistics.

Ramsbottom, R., Brewer, J., \& Williams, C. (1988). A progressive shuttle run test to estimate maximal oxygen uptake. Br J Sports Med., 22(4), 141-144.
Singapore Sports Council. (2002). NAPFA CHALLENGE: Your Test of Overall Physical Fitness (8th ed.). Singapore: National Physical Fitness Advisory Committee.

Southard, T. L., \& Pugh, J. W. (2004). Effect of Hydration State on Heart Rate-Based Estimates of VO2 Max. Journal of Exercise Physiology, 7(1), 19. Retrieved November 24, 2013 from http://www.asep. org/files/SouthardV2.pdf.

\section{Correspondence}

QUEK Chin Hwee Steven

Email: sq1967@hotmail.com 